\title{
Metal Workers and Plastic Workers
}

National Cancer Institute

\section{Source}

National Cancer Institute. Metal Workers and Plastic Workers. NCI Thesaurus. Code C122483.

The group of professions that include computer control prog rammers and operators; forming machine setters, operators, and tenders; machine tool cutting setters, operators, and tenders; machinists, metal furnace operators, tenders, pourers, and casters; model makers and patternmakers; molders and molding machine setters, operators, and tenders; multiple machine tool setters, operators, and tenders; tool and die makers; and welding, soldering, and brazing workers. 